\title{
UPAYA PENERAPAN MODEL PEMBELAJARAN TALKING STICK DALAM MENINGKATKAN HASIL BELAJAR SISWA PADA MATA PELAJARAN IPA DI KELAS IV SD NEGERI NO. 026609 BINJAI SELATAN
}

\author{
Herawati Bukit, Khairunnisa \\ * Dosen Jurusan PPSD Prosi PGSD FIP UNIMED \\ **Mahasiswa Jurusan PPSD Prosi PGSD FIP UNIMED \\ Surel : Khairunnisakhairunnisa18@gmail.com
}

\begin{abstract}
Abstrak
Penelitian yang dilakukan bertujuan untuk meningkatkan hasil belajar siswa pada mata pelajaran IPA pokok bahasan energi dan perubahannya dengan menggunakan model pembelajaran Talking Stick di kelas IV Binjai Selatan. Dari hasil temuan penelitian dapat disimpulkan bahwa hasil pretes tingkat ketuntasan hasil belajar sebanyak 10 siswa $28,57 \%$ dengan nilai rata-rata 56,57 pada siklus I hasil belajar siswa mengalami peningkatan sebanyak 15 orang siswa 42,85\% dengan rata-rata nilai 61,14 dan pada siklus II mengalami peningkatan menjadi sebanyak 30 orang siswa $85,71 \%$ dengan rata-rata nilai 75,14 sehingga baik secara individu maupun secara klasikal kemampuan awal (pre test) siswa masih tergolong belum tuntas. Pada siklus I terdapat 20 orang siswa $(57,14 \%)$ yang belum tuntas dan sebanyak 15 orang siswa $(42,85 \%)$ yang telah tuntas dalam belajar dengan rata-rata kelas 61,14 . Pada siklus II sebanyak 30 orang siswa $(85,71 \%)$ yang telah tuntas dalam belajar dan terdapat 5 orang siswa $(14,29 \%)$ yang belum tuntas dalam belajar dengan nilai rata-rata kelas 75,14.
\end{abstract}

Kata Kunci : Model, Talking Stick, Hasil Belajar

\section{PENDAHULUAN}

Pendidikan

merupakan

seluruh tahapan pengembangan kemampuan-kemampuan dan prilaku-prilaku manusia, juga proses penggunaan hamper seluruh pengalaman kehidupan. Untuk meningkatkan kualitas pendidikan bukanlah suatu hal yang mudah dilaksanakan karena ada faktor yang mempengaruhi, misalnya : pemahaman siswa dalam menguasai pokok bahasan yang diberikan, (2) guru harus memiliki pengetahuan dan keterampilan untuk mengajar seperti pendekatan atau model pembelajaran yang diberikan. Dengan demikian siswa diharapkan dapat meningkatkan keterlibatannya dalam kegiatan belajar mengajar dan tentunya dapat meningkatkan pemahamannya sendiri terhadap pokok bahasan. Oleh karena itu pendidikan memegang peranan yang sangat penting untuk menjamin kelangsungan hidup bangsa dan negara yaitu untuk menciptakan masyarakat yang cerdas dan pintar.

Selain itu, ada pun usaha yang harus dilakukan untuk 
menciptakan siswa yang cerdas dan pintar tersebut adalah dengan meningkatkan kompetensi guru dalam memilih model pembelajaran. Sebaiknya model pembelajaran yang dipilih adalah yang dapat meningkatkan keterlibatan siswa dalam proses pembelajaran, Karena sampai sekarang ini banyak siswa yang mengeluh IPA adalah pelajaran yang membosankan, sehingga mereka malas untuk mendalami pelajaran IPA tersebut. Hal ini membuat siswa cenderung kurang aktif yang menyebabkan perbuatanperbuatan atau tingkah laku dari siswa kurang terampil dalam menyampaikan ide dan gagasan mereka.

Disamping itu siswa terlihat kurang terampil berkomunikasi untuk menyampaikan informasi seperti menyatakan ide, mengajukan pertanyaan, dan menanggapi pertanyaan/pendapat orang lain. Mereka cenderung bersikap pasif/diam ketika guru mengajukan pertanyaan untuk mengecek pemahaman siswa, padahal sebenarnya mereka sudah memahami materi yang telah diajarkan dilihat dari tugas yang diberikan, baik disekolah maupun dirumah. Situasi tersebut terjadi kemungkinan karena siswa jarang diberikan kesempatan untuk berbicara,

Selain model pembelajaran yang dipelukan saat proses belajar mengajar berlangsung, adalah yang harus diperhatikan, yaitu media saat pembelajaran berlangsung. Banyak guru saat mengajar tidak menggunakan media pembelajaran. Padahal media pembelajaran itu sangatlah penting dalam proses belajar mengajar. Media pembelajaran berperan penting dalam meningkatkan ketertarikan siswa dalam belajar. Selain itu media untuk memudahkan siswa dalam memahami pelajaran dan juga dapat menarik minat siswa untuk belajar.

Dalam peningkatkan proses pembelajaran di sekolah, guru dituntut mampu dalam merancang dan melaksanakan kegiatan pembelajaran yang dapat mengembangkan kemampuan kognitif, afektif dan psikomotorik siswa agar tercapai hasil belajar yang optimal. Oleh karena itu dalam mendesain kegiatan pembelajaran yang optimal diperlukan kecermatan guru dalam memilih dan menerapkan model pembelajaran. Salah satunya dengan menerapkan model pembelajaran Talking Stick, pembelajaran dengan model Talking Stick dapat mendorong peserta didik untuk berani mengemukakan pendapat. Selain dengan menerapkan model pembelajaran Talking Stick guru diharapkan mengajar dengan menggunakan media untuk meningkatkan motivasi belajar anak. Oleh karena itu media sangat penting dalam proses belajar mengajar di sekolah untuk meningkatkan pemahaman saat pembelajaran berlangsung.

IPA (Ilmu Pengetahuan Alam) atau Sains berhubungan dengan cara mencari tahu tentang alam secara sistematis, sehingga 
sains bukan hanya penguasaan kumpulan pengetahuan yang berupa fakta-fakta, konsep atau prinsipprinsip saja tetapi juga merupakan suatu proses penemuan. Berdasarkan hasil pengamatan atau observasi yang dilakukan peneliti, masih kurangnya minat siswa untuk mengikuti pelajaran IPA, siswa kurang aktif dan kreatif dalam proses belajar mengajar yang dilaksanakan. Siswa cenderung tidak begitu tertarik dengan pelajaran IPA karena selama ini pelajaran IPA dianggap sebagai pelajaran yang hanya berdasarkan teori dan hapalan saja, guru cenderung menyampaikan materi pelajaran hanya dengan metode ceramah dan terkesan monoton tanpa banyak melibatkan siswa untuk bersikap aktif. Hal ini sangat berpengaruh kepada hasil belajar siswa yang kurang memuaskan dan dikategorikan rendah. Rendahnya hasil belajar siswa pada mata pelajaran IPA.

Rendahnya hasil belajar siswa kelas IV SD Negeri 026609 Binjai dalam mengikuti pelajaran IPA dapat dilihat dari nilai rata-rata ujian siswa yang belum mencapai KKM. Adapun KKM yang ditentukan dari sekolah yaitu 65, namun dari 35 orang siswa hanya ada 12 orang yang mencapai KKM, sedangkan 23 orang siswa lainnya dikatakan belum tuntas dalam menerima pelajaran.

Penjelasan diatas menunjukkan bahwa kriteria ketuntasan minimal (KKM) mata pelajaran IPA kelas IV di SD Negeri
026609 Binjai adalah 65. Berdasarkan hasil ujian tampak bahwa jumlah siswa yang tuntas belajar masih kurang dari 50\% sementara lebih dari $50 \%$ siswa yang masih belum mencapai ketuntasan dalam belajar IPA. Hal ini memberi indikasi bahwa prestasi belajar IPA siswa kelas IV di SD Negeri 026609 Binjai masih belum memuaskan.

Dengan banyaknya permasalahan pada pembahasan berkaitan dengan rendahnya hasil belajar siswa. Maka dari itu diharapkan guru memilih model pembelajaran yang tepat agar siswa lebih aktif dan bersemangat mengerjakan tugasnya pada waktu proses pembelajaran berlangsung..

Faktor yang mempengaruhi hasil belajar siswa tidak memuaskan dikarenakan selama ini guru selaku pengajar dalam menyampaikan materi pelajaran bersifat monoton, yakni pembelajaran IPA yang diajarkan masih menggunakan metode ceramah dam pemberian tugas. Guru merupakan satu-satunya sumber informasi bagi siswa, sehingga siswa dalam mengikuti pelajaran IPA cenderung merasa cepat bosan. Hal ini berdampak kepada hasil belajar siswa yang rendah.

Setelah penulis mempelajari model pembelajaran Talking Stick, penulis menganggap bahwa model pembelajaran ini sesuai untuk mengajarkan siswa pada pelajaran sains pokok bahasan energi dan perubahannya, karena siswa dapat berpikir, berani untuk 
mengemukakan pendapat dan memahami serta menerapkan dalam kehidupan sehari - hari.Selain itu, model pembelajaran Talking Stick tidak bersifat monoton melainkan belajar IPA menjadi menyenangkan. Model pembelajaran ini dilakukan dengan bantuan tongkat, siapa memegang tongkat wajib menjawab pertanyaan dari guru setelah siswa mempelajari materi pokoknya. Pembelajaran talking stick sangat cocok diterapkan bagi siswa SD, selain untuk melatih berbicara, pembelajaran ini akan menciptakan suasana menyenangkan dan membuat siswa aktif.

Model pembelajaran Talking

Stick ini akan meningkatkan motivasi belajar siswa pada pelajaran IPA. Siswa akan mengalami perubahan belajarnya, yaitu siswa yang sebelumnya belajar IPA cenderung membosankan dan tidak menarik, dalam model pembelajaran Talking Stick ini siswa akan dituntut untuk menggali pengetahuannya tentang IPA saat pembelajaran berlangsung. Dengan siswa diajak bekerja, siswa akan memahami konsep suatu materi dan nantinya diharapkan siswa dapat menggunakan daya nalarnya untuk menyelesaikan masalah - masalah yang ada.

Berdasarkan hasil observasi peneliti terhadap guru kelas 4, masih rendahnya hasil belajar siswa dalam pelajaran IPA, maka peneliti sangat tertarik untuk meneliti "Penerapan model pembelajaran Talking Stick dalam meningkatkan hasil belajar siswa pada mata pelajaran IPA dikelas IV SD Negeri No. 026609 Binjai Selatan.”

Berdasarkan latar belakang masalah di atas maka rumusan masalah penelitian ini adalah : "Apakah dengan penerapan model pembelajaran talking stick dapat meningkatkan hasil belajar siswa pokok bahasan energy dan perubahannya dikelas IVSD Negeri No.026609 Binjai Selatan?"

Mengingat begitu pentingnya suatu tujuan penelitian, maka tujuan penelitian ini adalah sebagai berikut : "Untuk mengetahui cara menerapkan model pembelajaran talking stick dalam meningkatkan hasil belajar siswa pada mata pelajaran IPA meningkat di kelas IV SD Negeri No.026609 Binjai Selatan.

\section{METODOLOGI PENELITIAN}

\section{Lokasi dan Waktu Penelitian}

a. Lokasi penelitian tindakan kelas ini dilaksanakan pada siswa di kelas IV SD Negeri No.026609 Sei Babalan Pujidadi Kecamatan Binjai selatan.

b. Waktu penelitian ini dilaksanakan selama dua bulan ( 2 bulan) dimulai dari tahap persiapan sampai dengan pelaksanaan tindakan dimulai dari bulan Maret sampai April. 


\section{Alat Pengumpulan Data}

Alat yang digunakan dalam mengumpulkan data pada penelitian ini adalah tes, dan observasi.

a. Tes

Tes adalah alat untuk memperoleh tentang kemampuan siswa dengan cara pemberian soal. Soal soal yang diberikan sebanyak 10 setelah setiap siklus dilakukan semua memuat materi energi dan perubahannya.

\section{b. Observasi}

Observasi adalah kegiatan yang dilakukan untuk mengamati kegiatan siswa selama proses pembelajaran berlangsung. Observasi yang dilakukan peneliti adalah peneliti mengajar di kelas IV dengan menggunakan format observasi yang telah disiapkan.

\section{HASIL PENELITIAN DAN PEMBAHASAN}

Dalam penelitian yang dilaksanakan di SD No.026609 Binjai, penelitian melakukan dua siklus setelah tes awal diberikan. Sebelum perencanaan tindakan dilakukan terlebih dahulu diberikan pretest kepada 35 siswa dengan tujuan untuk mengetahui kemampuan awal siswa dan juga mengetahui letak kesulitan- kesulitan yang dialami siswa dalam menyelesaikan soal energi dan
perubahannya.Berdasarkan hasil tes, pada saat pretest diperoleh data sebagai berikut:

\begin{tabular}{|c|c|c|c|}
\hline Nilai & $\begin{array}{c}\text { Jumlah } \\
\text { Siswa }\end{array}$ & $\begin{array}{c}\text { Persentase } \\
\text { jumlah } \\
\text { siswa }\end{array}$ & Keterangan \\
\hline $90-100$ & 4 & 11,43 & Meningkat \\
\hline $70-80$ & 6 & 17,14 & Meningkat \\
\hline $50-60$ & 17 & 48,57 & $\begin{array}{c}\text { T. } \\
\text { Meningkat }\end{array}$ \\
\hline$<40$ & 8 & 22,86 & $\begin{array}{c}\text { T. } \\
\text { Meningkat }\end{array}$ \\
\hline Jumlah & 35 & 100 & \\
\hline
\end{tabular}

Tabel 6. Deskripsi Nilai Pretes

Siswa

Dari test hasil yang diperoleh yang dilakukan pada saat sebelum diberi tindakan tersebut maka dapat diketahui dari 35 orang siswa kelas IV terdapat sebanyak 10 orang siswa $28,57 \%$ mendapat nilai meningkat, dan sebanyak 25 orang siswa $71,43 \%$ tidak meningkat.

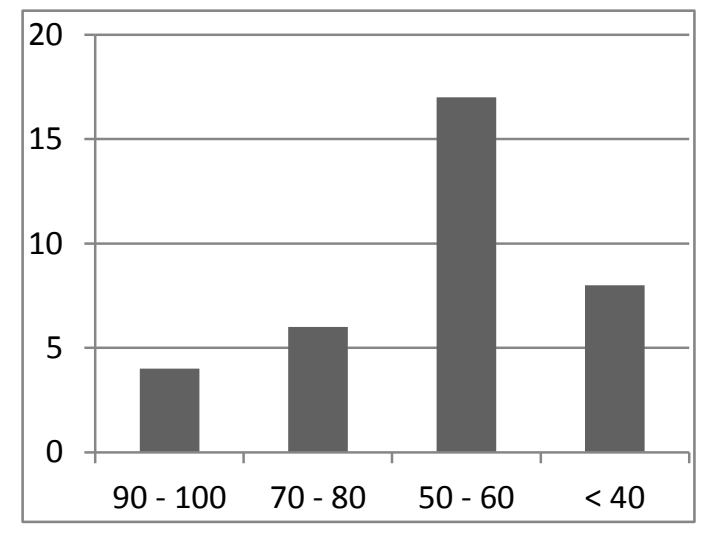

Grafik 1. Nilai Pretest Siswa

\section{Deskripsi Nilai Siklus I}

Guru meminta siswa untuk maju kedepan mengerjakan beberapa soal mengenai energi dan 
perubahannya. Hingga pada akhir pelaksanaan siklus I, guru memberikan post test I kepada siswa untuk melihat keberhasilan tindakan yang telah dilakukan dan untuk melihat kesulitan yang dialami siswa dalam pembelajaran, jumlah soal sebanyak 10 soal yang berbentuk pilihan berganda.

\begin{tabular}{|c|c|c|c|}
\hline Nilai & $\begin{array}{c}\text { Juml } \\
\text { ah } \\
\text { Sisw } \\
\text { a }\end{array}$ & $\begin{array}{c}\text { Persent } \\
\text { ase } \\
\text { Jumlah } \\
\text { Siswa }\end{array}$ & $\begin{array}{c}\text { Keteran } \\
\text { gan }\end{array}$ \\
\hline $\begin{array}{c}90- \\
100\end{array}$ & 4 & 11,43 & $\begin{array}{c}\text { Mening } \\
\text { kat }\end{array}$ \\
\hline $\begin{array}{c}70- \\
80\end{array}$ & 11 & 31,43 & $\begin{array}{c}\text { Mening } \\
\text { kat }\end{array}$ \\
\hline $\begin{array}{c}50- \\
60\end{array}$ & 16 & 45,71 & $\begin{array}{c}\text { T. } \\
\text { Mening } \\
\text { kat }\end{array}$ \\
\hline $\begin{array}{c}<40 \\
\text { T. } \\
\text { Mening } \\
\text { kat }\end{array}$ \\
\hline $\begin{array}{c}\text { Juml } \\
\text { ah }\end{array}$ & 35 & 11,43 & 100 \\
\hline
\end{tabular}

Tabel 8. Deskripsi Nilai Siklus I

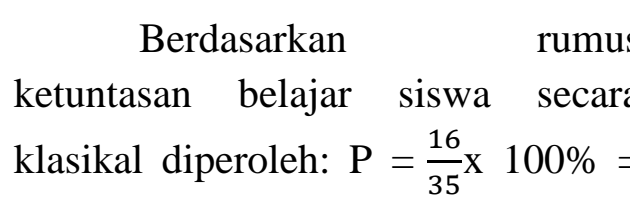
$45,71 \%$. Dari hasil test yang dilakukan pada siklus I tersebut maka dapat diketahui dari 35 orang siswa kelas IV terdapat 15orang siswa dengan persentase $42,85 \%$ mendapat nilai meningkat, dan sebanyak 20orang siswa dengan persentase $57,14 \%$ tidak meningkat.

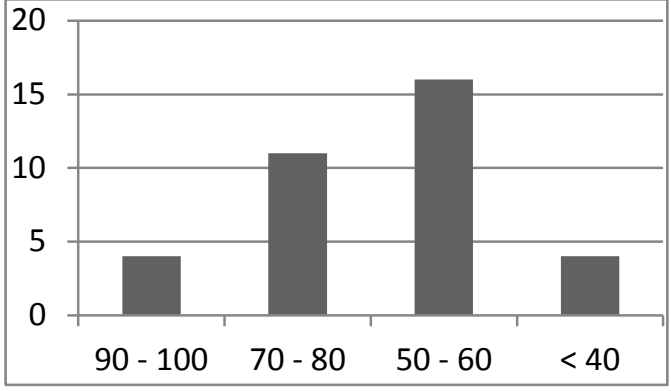

\section{Grafik 2. Hasil belajar siswa pada siklus I}

\section{Deskripsi Nilai Siklus II}

Guru meminta siswa untuk maju kedepan mengerjakan beberapa soal mengenai energi dan perubahannya. Hingga pada akhir pelaksanaan siklus II, guru memberikan post test II kepada siswa untuk melihat keberhasilan tindakan yang telah dilakukan dan untuk melihat kesulitan yang dialami siswa dalam pembelajaran, jumlah soal sebanyak 10 soal yang berbentuk pilihan berganda.

\begin{tabular}{|c|c|c|c|}
\hline Nilai & $\begin{array}{c}\text { Juml } \\
\text { ah } \\
\text { Sisw } \\
\text { a }\end{array}$ & $\begin{array}{c}\text { Persent } \\
\text { ase } \\
\text { Jumlah } \\
\text { Siswa }\end{array}$ & $\begin{array}{c}\text { Keterang } \\
\text { an }\end{array}$ \\
\hline $\begin{array}{c}90- \\
100\end{array}$ & 4 & 11,43 & $\begin{array}{c}\text { Meningk } \\
\text { at }\end{array}$ \\
\hline $\begin{array}{c}70- \\
80\end{array}$ & 26 & 74,28 & $\begin{array}{c}\text { Meningk } \\
\text { at }\end{array}$ \\
\hline $\begin{array}{c}50- \\
60\end{array}$ & 5 & 14,29 & $\begin{array}{c}\text { T.Menin } \\
\text { gkat }\end{array}$ \\
\hline$<40$ & & & 100 \\
\hline $\begin{array}{c}\text { Juml } \\
\text { ah }\end{array}$ & 35 & 100 & \\
\hline
\end{tabular}

Tabel 14. Deskripsi Nilai Siklus II

Berdasarkan rumus ketuntasan belajar siswa secara klasikal diperoleh: $\mathrm{P}=\frac{26}{35} \times 100 \%=$ $74,28 \%$. Dari hasil test yang dilakukan pada siklus II tersebut maka dapat diketahui dari 35 orang 
siswa kelas IV terdapat 30orang siswa dengan persentase $85,71 \%$ mendapat nilai meningkat, dan sebanyak 5orang siswa dengan persentase $14,29 \%$ tidak meningkat.

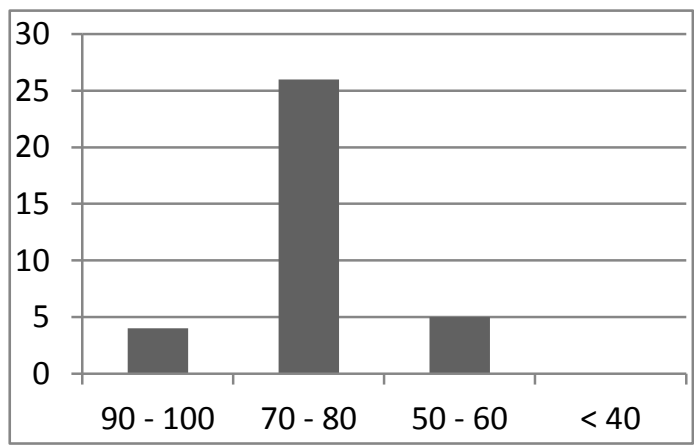

Grafik 3. Hasil belajar siswa pada siklus II

\section{Hasil Penelitian Pretest, Siklus I, dan Siklus II}

\begin{tabular}{|c|c|c|c|c|c|c|c|}
\hline \multirow{2}{*}{ Nilai } & \multicolumn{2}{|c|}{$\begin{array}{c}\text { Prete } \\
\text { st }\end{array}$} & \multicolumn{2}{c|}{$\begin{array}{c}\text { Siklus } \\
\text { I }\end{array}$} & \multicolumn{2}{c|}{$\begin{array}{c}\text { Siklus } \\
\text { II }\end{array}$} & \multirow{2}{*}{ Ket } \\
\cline { 2 - 7 } & F & $\%$ & F & $\%$ & F & $\%$ & \\
\hline $90-$ & 4 & 11, & 4 & 11, & 4 & 11, & Meningkat \\
100 & & 42 & & 43 & & 43 & \\
\hline $70-$ & 6 & 17, & 1 & 31, & 2 & 74, & Meningkat \\
80 & & 15 & 1 & 43 & 6 & 28 & \\
\hline $50-$ & 1 & 48, & 1 & 45, & 5 & 14, & T. \\
60 & 7 & 58 & 6 & 71 & & 29 & Meningkat \\
\hline$<40$ & 8 & 22, & 4 & 11, & 0 & 0 & T. \\
& & 85 & & 43 & & & Meningkat \\
\hline \multirow{2}{*}{ Jumlah } & $\mathbf{3}$ & $\mathbf{1 0}$ & $\mathbf{3}$ & $\mathbf{1 0}$ & $\mathbf{3}$ & $\mathbf{1 0}$ & \\
& $\mathbf{5}$ & $\mathbf{0}$ & $\mathbf{5}$ & $\mathbf{0}$ & $\mathbf{5}$ & $\mathbf{0}$ & \\
\hline
\end{tabular}

Tabel 20: Persentase Perubahan

Hasil Belajar Siswa pada Saat Pretest, Siklus I dan Siklus II

Dari tabel di atas dapat dilihat bahwa hasil belajar pada saat awal tindakan, siklus I dan siklus II menggunakan model pembelajaran Talking Stick mengalami peningkatan yang tampak pada persentase perubahan tingkat hasil belajar. Tingkat keberhasilan pembelajaran dengan menggunakan model pembelajaran Talking Stick dapat digambarkan seperti diagram berikut

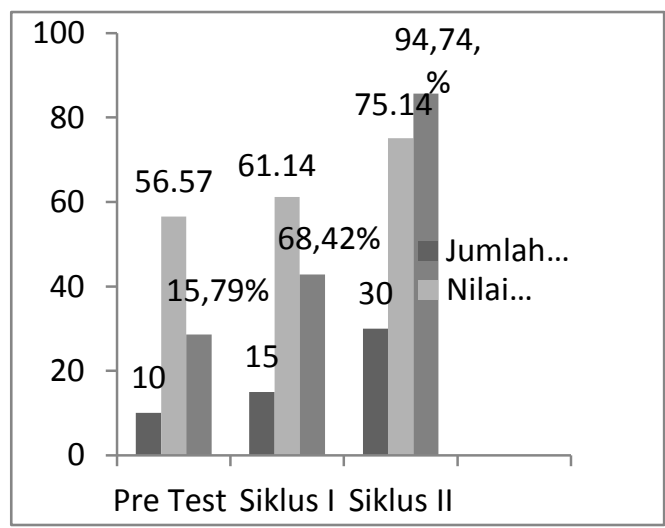

Grafik 4.Peningkatan Hasil Belajar Siswa pada saat Pretest, Siklus I dan Siklus II

\section{Temuan Penelitian}

\begin{tabular}{|c|c|c|c|c|c|}
\hline \multirow[b]{2}{*}{ Kegiatan } & \multirow[b]{2}{*}{$\begin{array}{c}\text { Aspek } \\
\text { Yang } \\
\text { Dinilai }\end{array}$} & \multirow[b]{2}{*}{$\begin{array}{c}\text { Jumlah } \\
\text { Siswa }\end{array}$} & \multirow[b]{2}{*}{ KKM } & \multicolumn{2}{|c|}{ Ket } \\
\hline & & & & $\begin{array}{l}> \\
\mathrm{K} \\
\mathrm{K} \\
\mathrm{M}\end{array}$ & $\begin{array}{l}< \\
\mathrm{K} \\
\mathrm{K} \\
\mathrm{M}\end{array}$ \\
\hline Pretes & Kogitif & 35 & 65 & 10 & 25 \\
\hline Siklus I & Kognitif & 35 & 65 & 15 & 20 \\
\hline Siklus II & Kognitif & 35 & 65 & 30 & 5 \\
\hline
\end{tabular}

Tabel 21. Ketuntasan Hasil Belajar Siswa Pada KKM

Berdasarkan tabel diatas dari 35 orang siswa pada saat pretes sebanyak 25 orang siswa yang mencapai nilai KKM 65, dan pada saat siklus II terdapat 30 orang siswa 
yang mendapat nilai meningkat, dan sebanyak 5 orang siswa yang tidak meningkat maka penelitian ini tidak dilanjutkan lagi ke siklus selanjutnya. Sebab hasil belajar sudah dapat ditingkatkan sesuai dengan nilai KKM (> 65) yang di tetapkan sekolah SD 026609 Binjai.

\section{SIMPULAN DAN SARAN Simpulan}

Berdasarkan hasil analisis data maka dapat diambil beberapa kesimpulan sebagai berikut:

a. Pada saat pretes dari 35 orang siswa diperoleh peningkatan klasikal sebanyak 10 orang siswa $28,57 \%$ mendapat nilai meningkat, dan sebanyak 25 orang siswa $71,43 \%$ mendapat nilai tidak meningkat dengan nilai rata-rata 56,57.

b. Pada siklus I terdapat sebanyak 15 orang siswa $42,85 \%$ mendapat nilai meningkat dan sebanyak 15 orang siswa $57,14 \%$ mendapat nilai tidak meningkat dengan nilai ratarata 61,14 .

c. Pada siklus II diperoleh peningkatam klasikal sebanyak 30 orang siswa $85,71 \%$ yang mendapat nilai meningkat, dan sebanyak 5 orang siswa $14,28 \%$ yang tidak meningkat dengan nilai rata-rata 75,14 .

d. Dengan demikian maka dapat disimpulkan

bahwa penggunaan model pembelajaran Talking Stick dapat meningkatkan hasil belajar siswa pada mata pelajaran IPA pokok bahasan Energi dan Perubahannya

Kelas IV SD Negeri No.026609 Binjai Selatan T.A 2014/2015.

\section{Saran}

a. Bagi sekolah menyediakan media pembelajaran yang dibutuhkan siswa sehingga proses pembelajaran menjadi menyenangkan.

b. Sebaiknya guru menggunakan model pembelajaran Talking Stick dalam meningkatkan hasil belajar siswa.

c. Kepada siswa diharapkan agar lebih aktif dalam proses pembelajaran agar diperoleh hasil belajar yang lebih baik.

d. Dapat dijadikan perbandingan dalam mengkaji variabelvariabel yang lebih luas tentang model pembelajaran Talking Stick.

\section{DAFTAR RUJUKAN}

Asmin dan Abil. 2012. Pengukuran dan Penilaian Hasil Belajar. Medan: Larispa.

Dewi, Rosmala, 2010. Penelitian Tindakan Kelas. Medan: Pasca Sarjana Unimed.

Dimyati dan Mudjiono. 2009. Belajar dan Pembelajaran. Jakarta: Rineka Cipta.

Istarani. 2012. 58 Model Pembelajaran Inovatif. Medan: Media Persada.

Muhibbinsyah, 2010. Psikologi Belajar. Jakarta: Rosda. 
Purwanto. 2011. Evaluasi Hasil Belajar. Yogyakarta: Pustaka Pelajar.

Rusman. 2011. Model-Model Pembelajara. Jakarta: Rajagrafindo Persada.

Samatowa, Usman. 2011. Pembelajaran IPA di Sekolah Dasar. Jakarta: Indeks.

Silberman, Melvin. 2006. Active Learning. Bandung: Nusa Media.

Slameto. 2010. Belajar dan FaktorFaktor yang Mempengaruhinya. Jakarta:

Rhineka Cipta.

Sudjana, Nana. 2009. Penilaian Hasil Proses Belajar Mengajar. Bandung: Rosda. 